\title{
Agronomic characters, genetic and phenotypic diversity coefficients, and heritability of 12 genotypes of rice
}

\author{
JAENUDIN KARTAHADIMAJA ${ }^{1,2, \bullet}$, SETYO DWI UTOMO ${ }^{3, \vee v}$, ERWIN YULIADI $^{3}$, ABDUL KADIR SALAM ${ }^{3}$, \\ WARSONO ${ }^{4}$, ANUNG WAHYUDI $^{1}$ \\ ${ }^{1}$ Departement of Agronomy, Politeknik Negeri Lampung. Jl. Soekarno Hatta No. 10, Rajabasa, Bandar Lampung 35144, Lampung, Indonesia. \\ Tel. +62-721-703995, fax. +62-721-787309, `email: jaenudinkartahadimaja @polinela.ac.id \\ ${ }^{2}$ Program of Agricultural Science, Graduates School, Universitas Lampung. J1. Sumantri Brojonegoro No. 1, Bandar Lampung 35145, Lampung, \\ Indonesia \\ ${ }^{3}$ Faculty of Agriculture, Universitas Lampung. J1. Sumantri Brojonegoro No. 1, Bandar Lampung 35145, Lampung, Indonesia. Tel. +62-721-701609, fax. \\ +62-721-702767, v•email: setyo.dwiutomo@fp.unila.ac.id \\ ${ }^{4}$ Faculty of Mathematics and Natural Sciences, Universitas Lampung. Jl. Sumantri Brojonegoro No. 1, Bandar Lampung 35145, Lampung, Indonesia
}

Manuscript received: 16 November 2020. Revision accepted: 29 February 2021.

\begin{abstract}
Kartahadimaja J, Utomo SD, Yuliadi E, Salam AK, Warsono, Wahyudi A. 2021. Agronomic characters, genetic and phenotypic diversity coefficients, and heritability of 12 genotypes of rice. Biodiversitas 22: 1091-1097. The achievement of national rice production is always below the target. One of the causes is the low productivity of the varieties grown due to the stagnant genetic capacity of these varieties. The assembly of new lines through breeding is one solution that can increase the genetic capacity of new varieties. Genetic diversity is one of the factors that influence the success of plant breeding. Ten new F9 rice lines were successfully assembled showing various phenotypes. The identification of the specific advantages of each of these new rice lines was based largely on the phenotypic response. The research objective was to identify the genetic advantages of each line through the analysis approach of genetic diversity coefficient (GDC), Phenotific Diversity Coefficient (PDC), and broad-sense heritability. The research was designed on a randomized completely block design (RCBD) with ten new $\mathrm{F}_{9}$ rice lines and two comparison varieties as treatments, repeated three times. The variables observed were plant height, maximum number of tillers, number of productive tillers, flowering time, harvesting time, panicle length, number of grain per panicle, number of filled grains per panicle, number of empty grain per panicle, grain length, grain width, grain thickness, and grain yield per hectare. The data were analyzed using Analysis of Variance (ANOVA), if there was a difference between the mean values, it was continued with a 5\% LSD test. The results showed that (i) the genotypes tested showed wide genetic and phenotypic diversity, (ii) based on the analysis of GDC, PDC, and broad sense heritability, the appearance of phenotypes of several agronomic characters was controlled by genetic factors.
\end{abstract}

Keywords: Agronomic characters, genetic diversity, heritability, phenotypic diversity, rice production

Abbreviations: GDC: diversity coefficient; PDC: phenotypic diversity coefficient

\section{INTRODUCTION}

Rice is one of the most important crops in the world because it can feed $50 \%$ of the world's population (Zhang et al. 2011; Kumar et al. 2018). In Indonesia, rice is the staple food ingredient for most of the population (Irawan 2015). The achievement of national rice production is always below the target. In order to maintain a balance between demand and production, almost all rice-producing countries have attempted to stabilize the rate of production through increasing crop productivity. Many factors cause the production below the target such as decrease in harvested area, pests and diseases, and low productivity of the varieties used (Central Bureau of Statistics of Riau Islands Province 2015). The low productivity of cultivated varieties is due to stagnant genetic capacity (Sobir 2013). The assembly of new lines through plant breeding is one of the solutions that can increase the genetic capacity of new varieties.. Plant breeding is an activity that aims to improve or increase the genetic potential of plants, in order to obtain new varieties that are better than the two parents (Purwati
2009). Genetic diversity is one of the factors that greatly contributes the success of plant breeding. The existence of genetic diversity in a population are variations in genotype values among individuals in the population (Sofiari and Kirana 2009).

Ten new rice lines of the $\mathrm{F}_{9}$ generation were successfully assembled showing various phenotypic appearances. The germplasm used as parents of the crosses comes from several national superior varieties, namely Gilirang, IR64, Cigeulis, and Ciherang which have different genetic diversity crossed with local superior varieties Mentik Wangi or Pandan Wangi which has high yield potential, and good quality rice showed by a fragrant rice aroma. Zuriates from the crosses starting from the $2^{\text {nd }}$ generation $(\mathrm{F} 2)$ were selected using the pedigreed method. Currently, there are 10 expected $9^{\text {th }}$ generation (F9) lines that have a superior phenotypic appearance. The identification of the specific advantages each of these new rice lines was primarily based on the phenotypic response. To increase the value of precision in increasing the genetic diversity of each line, it is necessary to identify the genetic 
advantages of each line through the analysis of the genetic diversity coefficient (GDC) approach, the coefficient of phenotypic diversity (PDC) and the estimated heritability value. Broad genetic diversity will affect the success of selection, and the success of selection is also influenced by the heritability level of the characters to be selected. The heritability prediction value shows whether a character is controlled by genetic factors or environmental factors, so that it can be seen to what extent the character can be passed on to the next offspring. The research objective was to identify the genetic superiority of each line through the analysis approach of the Genetic Diversity Coefficient (GDC), the Phenotific Diversity Coefficient (PDC), and the estimated heritability value.

\section{MATERIALS AND METHODS}

\section{Plant materials}

The germplasms used as the parent for the crossing were IR64, Gilirang, Cigeulis and Ciherang from national superior varieties which have different genetic diversity, and the local superior varieties, i.e., Mentik Wangi which have high yield potential and good quality in term of a rice fragrant aroma.

\section{F9 generation selection}

Zuriates of the crossing starting from the $2^{\text {nd }}\left(F_{2}\right)$ to the $6^{\text {th }}$ $\left(\mathrm{F}_{6}\right)$ generation were selected using the pedigree method to produce a segregating population that will be selected as new line candidates. Currently, 10 selected lines from the $\mathrm{F}_{9}$ generation have been produced and showed superior agronomic characters. The lines of hope show superior agronomic characters. The 10 lines are coded B2, B3, B4, B7, F2, F3, F4, H1, H4, and L2.

\section{Experiment design and analysis}

Ten new $\mathrm{F}_{9}$ rice lines and 2 commercial varieties were planted in the field using a randomized complete block design (RCBD). The varieties were used and treatment and each treatment was repeated three times. The maximum plant height, maximum number of tillers, number of productive tillers, $50 \%$ age of flowering plants, length of panicles, number of grains per panicle, number of filled grains per panicle, number of empty grain per panicle, grain yield per clump, and grain yield per hectare was observed. The data were analyzed using Analysis of Variance (ANOVA), if there was a difference between the mean values, the LSD at 5\% level was employed. To determine whether the phenotypic performance is influenced by genetic factors or environmental factors, analysis of Genetic Diversity Coefficient (GDC), the Phenotific Diversity Coefficient (PDC), and the estimated heritability value was applied for each observed variable. Genotypic diversity and phenotypic diversity $\left(\delta_{\mathrm{g}}^{2}, \delta_{\mathrm{p}}^{2}\right)$ were used to estimate the Genetic Diversity Coefficient (GDC) and the Phenotific Diversity Coefficient (PDC) using the following formula:

$$
\begin{aligned}
& \mathrm{GDC}=\frac{\sqrt{\delta_{g}^{2}}}{\bar{x}} \times 100 \% \\
& \mathrm{PDC}=\frac{\sqrt{\delta_{p}^{2}}}{\bar{x}} \times 100 \%
\end{aligned}
$$

Where:

GDC : Genetic Diversity Coefficient

PDC : Phenotific Diversity Coefficient

$\delta_{\mathrm{p}}^{2} \quad$ : Phenotific variance

$\delta_{\mathrm{g}}^{2} \quad$ : Genotific variance

$\bar{x} \quad$ : General average

Broad sense heritability was calculated according to the method of Singh and Chaudhary (1985); Fehr (1987).

$$
H_{B}^{2}=\frac{\delta_{g}^{2}}{\delta_{p}^{2}}
$$

Where:

$\delta_{\mathrm{p}}^{2} \quad$ : Phenotypic variance;

$\delta_{\mathrm{g}}^{2} \quad$ : Genotypic variance;

\section{RESULTS AND DISCUSSION}

\section{Growth variables}

The results of statistical analysis showed that the plant height, maximum number of tillers, number of productive tillers, width of flag leaves, length of flag leaves, and angles of flag leaves of 12 genotypes (10 lines and 2 varieties) varied among the genotypes (Table 1).

The plant height characters of 12 rice genotypes (10 lines and 2 varieties) showed significant variation. The F4 line showed the highest plant height about $145.98 \mathrm{~cm}$. Two lines, H4 and H1, as well as IR64 variety, showed lower than the other varieties. The twelve rice genotypes tested, if grouped based on plant height characters, can be grouped into three groups, i.e., (i) short plant, namely B4, F3, H1, H4 lines; (ii) medium plant, namely IR64 and Ciherang, B7, L2 lines, and; (iii) high plant, i.e., B2, B3, F2, and F4 (International Rice Research Institute 2002 and Yoshida 1981). The structure of rice plants is mainly determined by the condition of plant height, stem strength, number of tillers, leaf morphology and panicle (Kushwaha et al. 2015). Short and stiff rice stems are desirable traits in the development of superior rice varieties, because the plants become resistant to falling.

The capacity to produce maximum and productive tillers of the 12 rice genotypes tested showed character variation (Table 1). The $\mathrm{H} 4$ line shows the capacity to produce the maximum number of tillers a productive tillers. Based on the character of the ability to produce tillers, the 12 rice genotypes tested were categorized as the many tiller-producing rice. The capacity of the tillers is one of the important characteristics in high yielding varieties. The ability to produce tillers is a quantitative trait that contributes positively to rice productivity or yields (Constantino et al. 2015). Many tillers are expected to have a positive impact on the number of productive tillers. 
Table 1. The growth variables of 12 rice genotype observed

\begin{tabular}{|c|c|c|c|c|c|c|}
\hline Genotype & $\begin{array}{l}\text { Plant height } \\
\text { (cm) }\end{array}$ & $\begin{array}{c}\text { Maximum } \\
\text { number of tillers } \\
\text { (tiller) }\end{array}$ & $\begin{array}{c}\text { Maximum } \\
\text { number of tillers } \\
\text { (tiller) }\end{array}$ & $\begin{array}{c}\text { Flag leaf } \\
\text { width }(\mathrm{cm})\end{array}$ & $\begin{array}{c}\text { Flag leaf length } \\
(\mathrm{cm})\end{array}$ & $\begin{array}{l}\text { Flag leaf } \\
\text { angle }\left({ }^{\circ}\right)\end{array}$ \\
\hline B2(line) & $130.43 \mathrm{~b}$ & $32.40 \mathrm{bc}$ & $26.20 \mathrm{abcd}$ & $1.82 \mathrm{~b}$ & $34.88 \mathrm{bc}$ & $20.68 \mathrm{ab}$ \\
\hline B3 (line) & $132.96 \mathrm{~b}$ & $25.60 \mathrm{e}$ & $22.33 \mathrm{~d}$ & $2.14 \mathrm{a}$ & $37.75 \mathrm{~b}$ & $24.64 \mathrm{a}$ \\
\hline B4 (line) & $106.12 \mathrm{fg}$ & 27.87 cde & $24.73 \mathrm{abcd}$ & $1.88 \mathrm{~b}$ & $28.53 \mathrm{gh}$ & $17.61 \mathrm{bc}$ \\
\hline B7 (line) & $114.07 \mathrm{~d}$ & $26.53 \mathrm{de}$ & $24.00 \mathrm{abcd}$ & $1.87 \mathrm{~b}$ & $27.57 \mathrm{~h}$ & $15.89 \mathrm{bcd}$ \\
\hline F2 (line) & $133.73 \mathrm{~b}$ & $31.13 \mathrm{bcd}$ & $26.07 \mathrm{abcd}$ & $1.88 \mathrm{~b}$ & 30.34 efgh & $22.67 \mathrm{a}$ \\
\hline F3 (line) & 109.15 ef & $26.47 \mathrm{de}$ & $23.33 \mathrm{~cd}$ & $1.86 \mathrm{~b}$ & $33.17 \mathrm{cdef}$ & $17.22 \mathrm{bc}$ \\
\hline F4 (line) & $145.98 \mathrm{a}$ & 28.73 cde & $24.00 \mathrm{abcd}$ & $2.25 \mathrm{a}$ & $42.53 \mathrm{a}$ & $14.64 \mathrm{~cd}$ \\
\hline H1 (line) & $103.54 \mathrm{gh}$ & 27.87 cde & $23.60 \mathrm{bcd}$ & $1.90 \mathrm{~b}$ & 31.14 defg & $15.11 \mathrm{~cd}$ \\
\hline H4 (line) & $100.51 \mathrm{~h}$ & $39.13 \mathrm{a}$ & $28.73 \mathrm{a}$ & $1.82 \mathrm{~b}$ & $29.80 \mathrm{fgh}$ & $13,91 \mathrm{~cd}$ \\
\hline L2 (line) & $122.36 \mathrm{c}$ & $27.87 \mathrm{ab}$ & $28.27 \mathrm{ab}$ & $1.82 \mathrm{~b}$ & 31.25 defg & $12.20 \mathrm{~d}$ \\
\hline Var. IR-64 & $103.88 \mathrm{gh}$ & 31.13 cde & $22.20 \mathrm{~d}$ & $1.77 \mathrm{~b}$ & $34.01 \mathrm{~cd}$ & $15.93 \mathrm{bcd}$ \\
\hline Var. Ciherang & $111.25 \mathrm{de}$ & $31.73 \mathrm{bc}$ & $27.27 \mathrm{abc}$ & $1.82 \mathrm{~b}$ & 33.36 cde & $14.00 \mathrm{~cd}$ \\
\hline LSD & 4.45 & 4.86 & 4.78 & 0.23 & 3.38 & 4.90 \\
\hline
\end{tabular}

Note: The numbers followed by the same letter in the same column are not significantly different according to the 5\% LSD test

Productive tillers are tillers that produce panicles where the seeds or grains are located. The number of productive tillers per clump or per unit area determines the number of panicles as a yield component which will have a direct effect on the high and low potential yield of grain. Cultivars with the ability to produce large numbers of tillers have been the main objective of breeding programs since the 18th century for high yields (Liu et al. 2013). Many tiller types are suitable for a wide variety of spacing. The ability to produce many tillers will have an impact on the yield potential of a variety or line.

The characters of flag leaf length, flag leaf width, and flag leaf angle of the 12 rice genotypes tested showed differences (Table 1). Flag leaf is the top leaf that looks different in position and size from other leaves. The F4 and B3 lines are the two lines that have the widest flag leaf about 2.14-2.25 cm, and B4, F2 and $\mathrm{H} 4$ lines have the shortest flag leaf ranging from $27.57-30.34 \mathrm{~cm}$.

The leaf angles of the lines observed ranging from 12.20o-24.64o. A flag leaf angle of less than $45^{\circ}$ is an upright leaf plant category. The flag leaves act as an assimilate producer during the seed filling process. The ideal morphological characters of flag leaf include $50 \mathrm{~cm}$ length, $2 \mathrm{~cm}$ width, $5^{\circ}$ leaf angle, and narrow leaf to form the letter V (Peng et al. 2008). The desired characteristics of the leaves of the superior rice varieties are those that grow upright, thick, small and short. The effect of plant type on yield is highly dependent on the structure of the leaf canopy (Lu et al. 2010). Agronomically, the characters of rice varieties or lines with upright leaves are favored by farmers. In rice fields, which have an upright flag leaf character, are not favored by plant-disturbing organisms, especially birds, while those whose flag leaves are drooping, are preferred by birds because these pests will more easily perch at the base of the flag leaves and eat the grains.

\section{Yield component and yield variables}

The characters of flowering time, harvesting time, panicle length, filled grain of each panicle, empty grain of each panicle, and the total number of grains per panicle of the 12 rice genotypes varied widely (Table 2). Strains B2, B4, H1 and IR 64 are genotypes that are faster flowering and harvesting than the other lines. There are three genotypes, namely the B3, F4 and L2 lines which are slower flowering and harvesting. Based on the harvesting time, rice was categorized as aged $>151$ days after sowing (DAS); medium age (125-150) DAS; early age $105-124$ DAS; very early age 90 90-104 DAS; and ultra-early < 90 DAS (Indonesian Center for Rice Research 2016). Based on the age group categories, the 12 rice genotypes studied were categorized as early maturity, which ranged from 106.60 to115.93 days.

Observations on panicle length for the 12 rice genotypes (Table 2) showed variation/differences. The F4 line has a longer panicle length than the other genotypes, while the B4, H1, and $\mathrm{H} 4$ lines are three genotypes with shorter panicle lengths. The range of panicle length was $23.68 \mathrm{~cm}-29.90 \mathrm{~cm}$ and classified as the medium panicle length category (Diptaningsari 2013).

Rice plant panicles support the grain which is a sink that needs to be filled with photosynthate from various sources in the plant. Panicle achieves high yield when the number of grains per $\mathrm{m}^{2}$ is high, the percentage of filled grains is high, and the weight of 1000 filled grains is high. There are two genotypes that have the character of producing a higher total number of grain per panicle and filled grains of each panicle, namely the B3 and F4 lines. Although the length of the panicle is not too long in B3 line, it has capability to produce the highest number of total grain per panicle. This is the advantage of the B3 line because the location of the seeds or grain in the panicles is very tight, while other lines and varieties are rather rare. 
Table 2. Yield characteristics and components of 12 rice genotypes observed in this study

\begin{tabular}{|c|c|c|c|c|c|c|}
\hline Genotype & $\begin{array}{c}\text { Flowering time } \\
\text { (days) }\end{array}$ & $\begin{array}{l}\text { Harvest time } \\
\text { (days) }\end{array}$ & $\begin{array}{c}\text { Panicle } \\
\text { length }(\mathrm{cm})\end{array}$ & $\begin{array}{c}\text { Filled grain } \\
\text { panicle }^{-1} \text { (grains) }\end{array}$ & $\begin{array}{c}\text { Empty grain } \\
\text { panicle }^{-1} \text { (grains) }\end{array}$ & $\begin{array}{c}\text { Total grain } \\
\text { panicle }^{-1} \text { (grains) }\end{array}$ \\
\hline B2(line) & $62.60 \mathrm{fgh}$ & $106.60 \mathrm{~d}$ & $25,59 \mathrm{de}$ & $86.64 \mathrm{e}$ & $64.98 \mathrm{a}$ & $147.02 \mathrm{~cd}$ \\
\hline B3 (line) & $69.00 \mathrm{ab}$ & $115.93 \mathrm{a}$ & $26,31 \mathrm{~cd}$ & $185.49 \mathrm{a}$ & $30.38 \mathrm{ab}$ & $209.55 \mathrm{a}$ \\
\hline B4 (line) & $62.93 \mathrm{efgh}$ & $107.33 \mathrm{~d}$ & $23,68 \mathrm{~g}$ & $136.28 \mathrm{~cd}$ & $38.63 \mathrm{ab}$ & $175.03 \mathrm{bc}$ \\
\hline B7 (line) & $64.00 \mathrm{def}$ & $113.00 \mathrm{~b}$ & $26,23 \mathrm{~d}$ & $145.03 \mathrm{bcd}$ & $21.17 \mathrm{~b}$ & $166.28 \mathrm{bcd}$ \\
\hline F2 (line) & $65.67 \mathrm{c}$ & $110.53 \mathrm{c}$ & $27,01 \mathrm{c}$ & $119.31 \mathrm{~d}$ & $30.03 \mathrm{ab}$ & $148.12 \mathrm{~cd}$ \\
\hline F3 (line) & $64.20 \mathrm{de}$ & $106.47 \mathrm{~d}$ & 24,86 ef & $140.13 \mathrm{bcd}$ & $23.24 \mathrm{~b}$ & $162.97 \mathrm{bcd}$ \\
\hline F4 (line) & $70.20 \mathrm{a}$ & $115.67 \mathrm{a}$ & $29,90 \mathrm{a}$ & $171.47 \mathrm{ab}$ & $45.64 \mathrm{ab}$ & $218.29 \mathrm{a}$ \\
\hline H1 (line) & $62.53 \mathrm{~h}$ & $107.53 \mathrm{~d}$ & $23,68 \mathrm{~g}$ & $126.77 \mathrm{~d}$ & $31.92 \mathrm{ab}$ & 158.27 bcde \\
\hline H4 (line) & $64.00 \mathrm{def}$ & $107.00 \mathrm{~d}$ & $24,44 \mathrm{fg}$ & $143.00 \mathrm{bcd}$ & $11.60 \mathrm{~b}$ & $150.91 \mathrm{cde}$ \\
\hline L2 (line) & $68.67 \mathrm{~b}$ & $115.33 \mathrm{a}$ & $28,60 \mathrm{~b}$ & $137.42 \mathrm{~cd}$ & $24.78 \mathrm{~b}$ & 163.31 bcde \\
\hline Var. IR-64 & $60.73 \mathrm{i}$ & $106.87 \mathrm{~d}$ & $25,99 d$ & $116.39 \mathrm{de}$ & $32.24 \mathrm{ab}$ & $139.36 \mathrm{~d}$ \\
\hline Var. Ciherang & $64.47 \mathrm{~cd}$ & $111.40 \mathrm{c}$ & 25,19 ef & $160.16 \mathrm{abc}$ & $18.54 \mathrm{~b}$ & $176.44 \mathrm{~b}$ \\
\hline BNT & 1.45 & 1.23 & 0,76 & 32.38 & 38.82 & 24.79 \\
\hline
\end{tabular}

Note: The numbers followed by the same letter in the same column are not significantly different according to the 5\% LSD test

Grain quality is one of the selection parameters in rice plant breeding. The number of filled grains per panicle determines plant productivity. If the panicles produce a lot of dense grains, the productivity of rice plants is high. A large number of filled grains in each panicle and the small number of empty grains will determine the high quality of the plant (Mulyaningsih et al. 2016).

The grain size of the 12 genotypes studied varied in length, width and thickness (Table 3). The B3 line is one of the new rice lines which has the shortest grain length character of $8.30 \mathrm{~mm}$ (classified as the medium-grain length category), but it has the widest grain width character, while the other nine lines are ranging from 9.04$10.31 \mathrm{~mm}$ and including as the long grain category. Other lines, such as B2, B4, B7, F2, F3, F4, H1, H4, L2, and two varieties IR 64 and Ciherang, have a long grain length with a narrower grain. IR 64 is the smallest (narrow) grain rice that has only $2.55 \mathrm{~mm}$ width.

The weight of 1000 filled grains of the 12 rice genotypes tested was different (Table 3). The F4 line has the weighest 1000 filled grains, i.e., $33.40 \mathrm{~g}$ compared to other genotypes. The F3, H4, and Ciherang varieties are three genotypes that have lower 1000 grains weight of filled grain. The weight of the 12 rice genotypes tested was ranging from 26.79 to $33.40 \mathrm{~g}$. The 1000 grains weight of most paddy fields is about $25 \mathrm{~g}$.. The weight of 1,000 filled grains is more dominated by plant genetic factors (Kartina et al. 2017). The yield components do not work independently, in general, they are interrelated with each other which ultimately produces the grain. Most characters of yield components are inherited and some of them are not (Hasanuzzaman et al. 2010).

\section{Grain shape characters}

Qualitatively, the grain characters of the 12 rice genotypes studied (10 lines and 2 varieties) were observed and they had different characters (Figure 1). The three genotypes such as B2, F4, and H4 strains have hairy or tail tips, in which the F4 line at the end of the tail is longer than the B2, and $\mathrm{H} 4$ lines. Other genotypes are hairless (Figure 1).

Thus, the 12 rice genotypes tested are grouped into two characters, namely the hairy and hairless rice. The hairy rice is included in the Javanica cultivar group, while the hairless rice are included in the Indica cultivar group.

\section{Rice shape characters}

The grain was then peeled off and the husk was removed to becomes cracked rice (Figure 2) and then the length, width and length/width ratio were measured. The measurements and characterization were carried out according to the Ministry of Environment and Forests Government of India (2011).

The results of characterization, of the 12 rice genotypes tested, there were two characters of rice shape, i.e., medium and (lean/slender character. Four genotypes (B2, B3, F2, and H1) lines are classified as medium rice shape which has a length/width ratio between 2.4-3.0 mm. The other eight genotypes, i.e., B4, B7, F3, F4, H4, L2, IR64, and Ciherang, are grouped into slender grain shape characters because they have a length/width ratio $>3.0 \mathrm{~mm}$ ) (Table 4).

\section{Genotypic diversity coefficient (GDC), phenotypic diversity coefficient (PDC), and heritability}

The genetic variability criterion is determined by comparing genetic variability with its standard deviation. The observed variable has a wide genetic variability value if the value of genetic variability is equal to or greater than twice the standard deviation of genetic variance $\left(\sigma^{2} \mathrm{~g}>2 . \mathrm{Sd}\right.$ $\sigma^{2} \mathrm{~g}$ ) and the phenotypic variability is referred to as broad genetic variability if the value of the phenotypic variance is equal to or greater than twice the standard deviation of the variance $\left(\sigma^{2} f>2 . S d \sigma^{2} f\right)($ Qosim at al. 2013). 
Table 3. Characteristics of grain size, weight of 1000 filled grains, and yield potential of 12 rice genotypes

\begin{tabular}{lccccc}
\hline Genotype & Grain length $(\mathbf{m m})$ & $\begin{array}{c}\text { Grain width } \\
(\mathbf{m m})\end{array}$ & $\begin{array}{c}\text { Grain } \\
\text { thickness }(\mathbf{m m})\end{array}$ & $\begin{array}{c}\text { Weight of 1000 grains } \\
\text { of filled grain }(\mathbf{g})\end{array}$ & $\begin{array}{c}\text { Grain yield per } \\
\text { hecta (ton) }\end{array}$ \\
\hline B2(line) & $10.05 \mathrm{abc}$ & $3.13 \mathrm{bc}$ & $2.10 \mathrm{a}$ & $31,56 \mathrm{~b}$ & $11.56 \mathrm{ab}$ \\
B3 (line) & $8.30 \mathrm{f}$ & $3.37 \mathrm{a}$ & $2.05 \mathrm{abc}$ & $30,10 \mathrm{c}$ & $12.00 \mathrm{a}$ \\
B4 (line) & $10.00 \mathrm{bcd}$ & $2.86 \mathrm{~d}$ & $2.06 \mathrm{abc}$ & $28,88 \mathrm{cdef}$ & $10.19 \mathrm{cde}$ \\
B7 (line) & $9.96 \mathrm{bcd}$ & $2.76 \mathrm{de}$ & $2.03 \mathrm{abc}$ & $28,57 \mathrm{def}$ & $10.81 \mathrm{bc}$ \\
F2 (line) & $9.01 \mathrm{e}$ & $3.05 \mathrm{c}$ & $2.06 \mathrm{abc}$ & $28,33 \mathrm{defg}$ & $7.86 \mathrm{f}$ \\
F3 (line) & $9.70 \mathrm{~cd}$ & $2.77 \mathrm{de}$ & $1.98 \mathrm{c}$ & $28,09 \mathrm{fgh}$ & $10.44 \mathrm{~cd}$ \\
F4 (line) & $10.31 \mathrm{ab}$ & $2.77 \mathrm{~b}$ & $2.04 \mathrm{abc}$ & $33,40 \mathrm{a}$ & $11.72 \mathrm{ab}$ \\
H1 (line) & $9.04 \mathrm{e}$ & $3.05 \mathrm{c}$ & $2.08 \mathrm{ab}$ & $29,89 \mathrm{~cd}$ & $7.71 \mathrm{f}$ \\
H4 (line) & $9.64 \mathrm{~d}$ & $2.79 \mathrm{de}$ & $2.01 \mathrm{bc}$ & $27,13 \mathrm{gh}$ & $9.66 \mathrm{de}$ \\
L2 (line) & $10.41 \mathrm{a}$ & $2.84 \mathrm{de}$ & $2.07 \mathrm{abc}$ & $29,53 \mathrm{cde}$ & $10.70 \mathrm{bcd}$ \\
Var. IR-64 & $9.64 \mathrm{ab}$ & $2.55 \mathrm{f}$ & $2.06 \mathrm{abc}$ & $26.79 \mathrm{~h}$ & $8.03 \mathrm{f}$ \\
Var. Ciherang & $9.79 \mathrm{~cd}$ & $2.74 \mathrm{e}$ & $2.05 \mathrm{abc}$ & $28.49 \mathrm{defg}$ & $9.26 \mathrm{e}$ \\
LSD & 0.40 & 0.12 & 0.09 & 1.41 & 1.11 \\
\hline NS & & 0.12 & \\
\hline
\end{tabular}

Note: The numbers followed by the same letter in the same column are not significantly different according to the 5\% LSD test

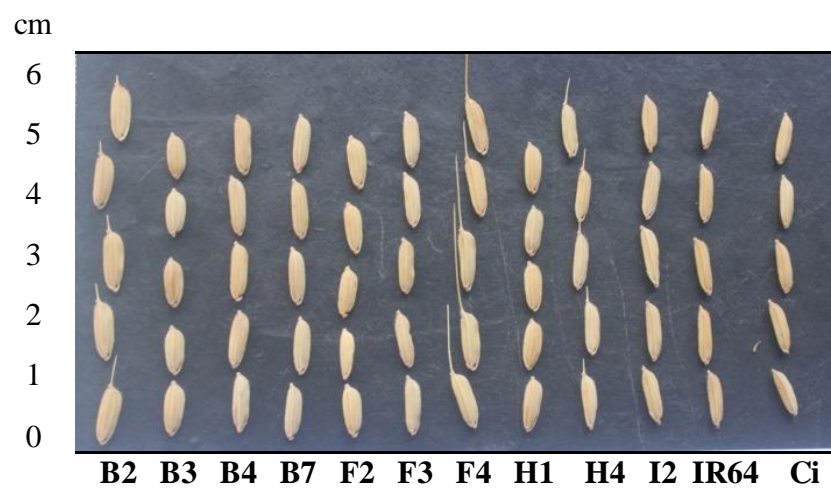

Figure 1. Grain characteristics of 12 rice genotypes. Ci: Ciherang

Table 4. Size and shape characters of 12 genotypes of rice

\begin{tabular}{lcccl}
\hline Genotype & $\begin{array}{c}\text { Rice length Rice width length/width } \\
\text { (mm) }\end{array}$ & $\begin{array}{c}\text { Character } \\
\text { (mm) }\end{array}$ & $\begin{array}{lll}\text { ratio }(\mathbf{m m}) \\
\text { of rice shape }\end{array}$ \\
\hline & & & & \\
B2(line) & 7.52 & 2.55 & 2.97 & Medium \\
B3 (line) & 6.43 & 2.78 & 2,31 & Medium \\
B4 (line) & 7.38 & 2.36 & 3.12 & Slim \\
B7 (line) & 7.45 & 2.30 & 3.24 & Slim \\
F2 (line) & 6.24 & 2.45 & 2.55 & Medium \\
F3 (line) & 7.63 & 2.12 & 3.60 & Slim \\
F4 (line) & 7.51 & 2.49 & 3.02 & Slim \\
H1 (line) & 6.43 & 2.56 & 2.51 & Medium \\
H4 (line) & 7.12 & 2.19 & 3.25 & Slim \\
L2 (line) & 7.97 & 2.32 & 3.44 & Slim \\
Var. IR-64 & 7.35 & 1.96 & 3.75 & Slim \\
Var. Ciherang & 7.30 & 2.09 & 3.49 & Slim \\
& & & & \\
\hline
\end{tabular}

Note: Slim shape (length/width ratio > 3mm); Medium form (length/width ratio 2.4-3.0) (Ministry of Environment and Forests Government of India, 2011)

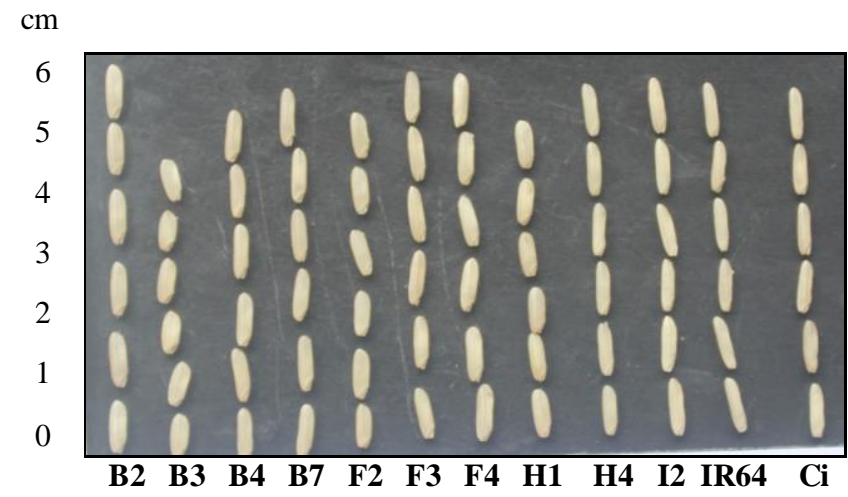

Figure 2. Rice shape characters of 12 rice genotypes. Ci: Ciherang

The results of statistical analysis, genetic and phenotypic variability for the characters of maximum plant height, number of tillers, flag leaf length, flag leaf angle, flowering time, harvesting time, panicle length, filled grain per panicle, total grain per panicle, grain length, grain width, weight 1000 grains of filled grain, and grain yield per hectare have wide genetic and phenotypic variability values. This can be seen from the magnitude of the value of genetic variance and phenotype variety which is greater than twice the standard deviation of genetic variance and phenotypic variety (Table 5). This shows that the agronomic characters between genotypes are very diverse. Genetic and phenotypic diversity is one of the factors that greatly influence the success of plant breeding efforts. The presence of genetic and phenotypic diversity in a population means that there are variations in genotype and phenotype values between individuals in the population (Sofiari et al. 2009). The wide diversity of characters will provide good opportunities in the selection process because the process of improving plant character is as expected. 
Table 5. Values of environmental variety, genetic variety, phenotypic variety, heritability, GDC and PDC 12 rice genotypes

\begin{tabular}{|c|c|c|c|c|c|c|c|}
\hline Observation variable & $\sigma^{2} e$ & $\sigma^{2} \mathbf{g}$ & $\sigma^{2} p$ & $\begin{array}{c}2 \times s d \\
\sigma^{2} g\end{array}$ & GDC & PDC & $\begin{array}{c}\text { Heritability } \\
\left(h^{2}\right)_{B S}\end{array}$ \\
\hline Plant height & 6.91 & 217.89 & 220.20 & 172.74 & 12.53 & 12.59 & 0.99 \\
\hline Maximum number of tillers & 8.25 & 13.21 & 15.97 & 12.63 & 12.11 & 13.31 & 0.47 \\
\hline Number of productive tillers & 7.98 & 2.25 & 4.91 & 4.15 & 5.99 & 8.84 & 0.46 \\
\hline Flag leaf width & 0.02 & 0.01 & 0.02 & 0.02 & 6.19 & 7.47 & 0.69 \\
\hline Flag leaf length & 3.98 & 16.06 & 17.39 & 13.66 & 12.20 & 12.69 & 0.92 \\
\hline Flag leaf angle & 8.37 & 11.53 & 14.31 & 11.34 & 19.92 & 22.20 & 0.81 \\
\hline Flowering time & 0.73 & 8.31 & 8.55 & 6.71 & 4.44 & 4.51 & 0.97 \\
\hline Harvest time & 0.52 & 14.55 & 14.72 & 11.55 & 3.46 & 3.48 & 0.99 \\
\hline Panicle long & 0,20 & 3,43 & 3,50 & 2,74 & 7,14 & 7,21 & 0,98 \\
\hline Grain fill each panicle & 365.71 & 561.40 & 683.30 & 540.63 & 17.05 & 18.80 & 0.82 \\
\hline Empty grain every panicle & 525.68 & 20.96 & 196.19 & 184.18 & 14.72 & 45.04 & 0.11 \\
\hline Total grain of each panicle & 214.37 & 516.58 & 588.03 & 463.13 & 13.53 & 14.44 & 0.88 \\
\hline Grain length & 0.06 & 0.37 & 0.39 & 0.31 & 6.27 & 6.43 & 0.95 \\
\hline Grain width & 0.005 & 0.06 & 0.06 & 0.04 & 8.06 & 8.17 & 0.97 \\
\hline Grain thickness & 0.003 & 0.00 & 0.001 & 0.001 & 0.47 & 1.50 & 0.10 \\
\hline The weight of 1000 grains of filled grain & 0.69 & 3.19 & 3.42 & 2.69 & 6.11 & 6.33 & 0.93 \\
\hline Grain yield per hectare & 0.43 & 2.14 & 2.29 & 1.80 & 14.65 & 15.13 & 0.94 \\
\hline
\end{tabular}

Genotypic Diversity Coefficient (GDC) and Phenotypic Diversity Coefficient (PDC) values for plant height, flag leaf length, flag leaf angle, flowering time, harvesting time, panicle length, number of filled grains per panicle, total number of grain per panicle, grain length, grain width, weight of 1000 filled grains, and grain yield per hectare are almost equal (coincide), while the characters of the maximum tillers, the number of productive tillers, the number of empty grains per panicle, and the grain thickness, have a PDC value that is higher than the value GDC (Table 5).

The criteria for the value of the GDC and PDC scores are low (0-25\%), rather low (25-50\%), quite high (50$75 \%$ ), high (75-100\%) (Moedjiono and Mejaya 1994). The GDC and PDC scores of the 15 characters observed are low. This gives an indication that the characters that appear from each genotype show uniform and stable conditions. The low values of the Genotypic Diversity Coefficient (GDC) and the Phenotypic Diversity Coefficient (PDC) for the character of plant height, flag leaf length, flag leaf angle, flowering time, harvesting time, panicle length, number of filled grains per panicle, total number of grain per panicle, length Grain, grain width, weight of 1000 filled grains, and grain yield per hectare which are almost equal or coincide, indicate that the diversity of a character is more due to genetic factors (Hapsari et al. 2010). Thus, if the 12 rice genotypes tested were planted in another place with a different environment, the possibility of character changes was very low.

According to Jalata et al. (2011), the PDC value that is higher than the GDC indicates that the selection can be made based on the diversity of these characters. PDC which is higher than GDC also shows that the diversity seen in these characters is more influenced by environmental factors than genotypic factors. The GDC value which is close to or almost the same as the PDC indicates that environmental factors have little effect on the diversity that occurs in the characters tested, so that selection can be effectively carried out on these characters based on their performance (Yasinda et al 2015).

Heritability values for the characters of plant height, flag leaf width, flag leaf length, flag leaf angle, flowering time, harvesting time, panicle length, filled grain per panicle, total grain per panicle, grain length, grain width, weight of 1000 filled grains, and grain yield per hectare showed broad sense heritability values $\left(h^{2}{ }_{B S}\right)$ ranging from 0.69 to 0.99 (Table 5). This shows that all the characters observed have high heritability values. The characters of the maximum number of tillers and the number of productive tillers produced by the 12 genotypes had a heritability value between 4.6-4.7 which was in the moderate category, and the character of the number of empty grains per panicle and grain thickness character had low heritability, i.e., $0.10-0.11$.

Heritability is a genetic parameter used to measure the level of inheritance of a character in a plant population or an estimate that measures the extent to which the variability of a character's appearance in the population is caused by the role of genetic factors. If a character has a high heritability value, the appearance of that character is more controlled by genetic factors, so that the character can be referred to as a character that is easily inherited. Genetic factors play a more important role in controlling a trait than environmental factors (Barmawi 2013; Hermanto et al. 2017). In order to release a line as a new high-yielding variety, one of the conditions that must be fulfilled by the line concerned is its population in a uniform line.

\section{ACKNOWLEDGEMENTS}

The author would like to thank DRPM, Indonesia Ministry of Research, Technology and Higher Education (Kemenristek Dikti) for funding this research, as well as to 
the Politeknik Negeri Lampung Research and Community Service Unit (RCSU) that helped to carry out this research.

\section{REFERENCES}

Barmawi M, Yushardi A, Sa'diyah N. 2013. Daya waris dan harapan kemajuan seleksi karakter agronomi kedelai Generasi F2 hasil persilangan antara Yellow bean dan Taichung. Jurnal Agrotek Tropika 1 (1): 20-24. [Indonesian]

Central Bureau of Statistics of Riau Province. 2015. Gross Regional Domestic Product Riau Province by Industrial Origin 2011-2015. Catalog Number: 9302021.14.

Constantino KP, Gonzales EJ, Lazaro LM, Serrano EC, Samson BP. 2015 Height measurement and tiller segmentation of rice crops using image processing. Proceeding of DLSU Research Congress 3: 1-6.

Diptaningsari D. 2013. Analisis keragaan karakter agronomis dan stabilitas galur harapan padi gogo turunan padi local Pulau Buru hasil kultur antera. [Tesis]. Institut Pertanian Bogor, Bogor. [Indonesian]

Hapsari RT, Adie MM. 2010. Pendugaan parameter genetik dan hubungan antar komponen hasil kedelai. Jurnal Penelitian Pertanian Tanaman Pangan 29 (1): 18-23. [Indonesian]

Hermanto R, Syukur M, Widodo. 2017. Pendugaan ragam genetik dan heritabilitas karakter hasil dan komponen hasil tomat (Lycopersicum esculentum Mill.) di dua lokasi. J Hort Indonesia 8 (1): 31-38. DOI: 10.29244/jhi.8.1.31-38. [Indonesian]

Irawan B. 2015. Memperkuat kemampuan swasembada pangan [Strengthening food self-sufficiency capabilities] (Jakarta: IAARD Press, Badan Penelitian dan Pengembangan Pertanian Indonesia [Agency for Agricultural Research and Development Indonesia]) Dinamika produksi padi sawah dan padi gogo: Implikasinya terhadap kebijakan peningkatan produksi padi [Dynamics of rice and upland rice production: Implications for the policy to increase rice production] 68-88. [Indonesian]

Jalata Z, Ayana A, Zeleke H. 2011. Variability, heritability, and genetic advance for some yield and yield related traits in Ethiopian barley (Hordeum vulgare L.) landraces and crosses. Intl J Plant Breeding and Genet 5 (1): 44-52. DOI: 10.3923/ijpbg.2015.68.76

Kartina N, Wibowo BP, Rumanti IA, Satoto. 2017. Korelasi hasil gabah dan komponen hasil padi hibrida. Jurnal Penelitian Pertanian Tanaman Pangan 1 (1): 11-19. [Indonesian]

Kumar S, Chauhan MP, Tomar A, Kasana RK. 2018. Coefficient of variation (GCV \& PCV), heritability and genetic advance analysis for yield contributing characters in rice (Oryza sativa L.). J Pharmacog Phytochem 7 (3): 2161-2164.
Kushwaha UKS, Khatiwada SP, Upreti HK, Shah US, Thapa DB, Dhami NB, Gupta SR, Singh PK, Mehta KR, Sah SK, Chaudhary B, Tripathi BP. 2015. Modification of rice breeding technology in 21st Century. Intl J Bioinform Biomed Engineer 1 (2): 77-84.

Liu Y, Yu L, Tong J, Ding J, Wang R, Lu Y, Xiao L. 2013. Tiller number is altered in the ascorbic acid-deficient rice suppressed for galactinol1,4-lactone dehydrogenase. J Plant Physiol 170 (4): 389-396. DOI: 10.1016/j.jplph.2012.11.019

Lu CG, Hu N, Yao KM, Xia SJ, Qi QM. 2010. Plant type and its effects on canopy structure at heading stage in various ecological areas for a two-line hybrid rice combination, Liangyoupeijiu. Rice Sci 17: 235242. DOI: $10.1016 / \mathrm{S} 1672-6308(09) 60022-6$

Ministry of Environment and Forests Government of India. 2011. Biology of Oryza sativa L.(Rice). Department of Biotechnology Ministry of Science Technology and Ministry of Environment and Forests.

Hasanuzzaman M, Ahamed KU, Rahmatullah NM, Akhter N, Nahar K, Rahman ML. 2010. Plant growth characters and productivity of wetland rice (Oryza sativa L.) as affected by application of different manures. Emir. J Food Agric 22 (1): 46-58.

Mulyaningsih ES, Perdani AY, Indrayani S, Suwarno. 2016. Seleksi fenotipe populasi padi gogo untuk hasil tinggi, toleran alumunium dan tahan blast di tanah masam. Jurnal Penelitian Pertanian Tanaman Pangan 35 (3): 191-197. DOI: 10.21082/jpptp.v35n3.2016.p191-197. [Indonesian]

Peng S, Khush GS, Virk P, Tang Q, Zou Y. 2008. Progress in ideotype breeding to increase rice yield potential. Field Crop Res 108 (1): 32 38. DOI: $10.1016 / \mathrm{j}$.fcr.2008.04.001

Purwati. 2009. Daya hasil tomat F1 (Hibrida) di dataran medium. Jurnal Hortikultura 19 (2): 125-130. [Indonesian]

Qosim WA, Rachmadi M, Hamdan JS, Nuri I. 2014. Penampilan fenotipik, variabilitas, dan heritabilitas 32 genotipe cabai merah berdaya hasil tinggi. Jurnal Agronomi Indonesia 41 (2). DOI: 10.24831/jai.v41i2.7519. [Indonesian]

Sobir. 2013. Optimalisasi lahan suboptimal bagi penguatan ketahanan pangan Indonesia. Prosiding Seminar Nasional Lahan Suboptimal Intensifikasi Pengelolaan Lahan Suboptimal dalam Rangka Mendukung Kemandirian Pangan Nasional. Palembang, 20-21 September 2013: 23-27. [Indonesian]

Sofiari E, Kirana R. 2009. Analisis pola segregasi dan distribusi beberapa karakter cabai. J Hort 19 (3): 255-263. [Indonesian]

Yasinda AA, Sutjahjo SH, Marwiyah S. 2015. Karakterisasi dan evaluasi keragaman genotipe semangka lokal. Bul Agrohorti 3 (1): 47-58. [Indonesian]

Zhang P, Li J, Li X, Liu X, Zhao X, Lu Y. 2011. Population structure and genetic diversity in a rice core collection (Oryza sativa L.) investigated with SSR markers. PLoS ONE 6 (12): e27565. DOI: 10.1371/journal.pone.0027565. 